\title{
OPIOID CONTROL OF GROWTH HORMONE IN THE SUCKLED SOW IS PRIMARILY MEDIATED THROUGH GROWTH HORMONE RELEASING FACTOR
}

\author{
J.D. Armstrong , K.L. Esbenshade , M.T. Coffey , \\ E. Heimer , R. Campbell , T. Mowles and A. Felix
}

\begin{abstract}
Endogenous opioid peptides mediate the effect of suckling on LH and PRL in the domestic pig. However, the role of opioids in modulating GH during lactation in swine is not known. Primiparous sows that had been immunized against GRF(1-29) conjugated to human serum albumin (GRF-HSA, $n=5$ ) or HSA $(n=4)$ were used to determine changes in GH after naloxone. Treatments were imposed in all sows on day 21 of lactation when antibody titers were $9100 \pm 1629$. All sows received (i.v.) naloxone $(0.25 \mathrm{mg} / \mathrm{kg})$ or saline $(0.0125 \mathrm{ml} / \mathrm{kg})$ at $15 \mathrm{~min}$ intervals for $165 \mathrm{~min}$. Active immunization against GRF-HSA during lactation decreased $(P<0.05)$ mean concentration $(4.8 \pm 0.2$ vs $2.6 \pm 0.1 \mathrm{ng} / \mathrm{ml})$ and frequency $(1.5 \pm 0.3$ vs $0.4 \pm 0.2$ peaks $/ 4 \mathrm{hr})$ Concentrations of LH and PRL were similar in GRF-HSA and HSA immunized sows. Naloxone suppressed (P $<0.05)$ GH in all sows. In HSA sows, naloxone abolished episodic release of $\mathbf{G H}$ and decreased average, but not basal, concentrations of $\mathbf{G H}$. In sows immunized against GRF-HSA, naloxone decreased $(P<0.05)$ average and basal GH but failed to decrease frequency of GH release. Naloxone failed to alter frequency of LH release. Concentrations of PRL decreased $(P<0.05)$ after naloxone in all sows. In conclusion, immunization against GRF-HSA blocked most of the effect of lactation on GH. Blocking opioid receptors with naloxone decreased GH and PRL in all sows. In contrast to previous findings naloxone had no effect on LH. Opioids alter concentrations of GH through a GRF dependent and GRF independent pathway.
\end{abstract}

\section{INTRODUCTION}

During lactation, suckling by piglets causes PRL to be elevated and LH release to be suppressed, effects which are mediated through endogenous opioid peptides (1-5). Infusion or single injection of the opioid antagonist naloxone increased $\mathrm{LH}(2,4,5)$ and decreased PRL $(2,5)$. Administration of morphine prevented the rise in LH induced by transient removal of the litter (cessation of suckling, 3). Growth hormone is lactogenic in mammals, but less is known about control of GH during lactation in the pig. Naloxone decreased $G H$ in lactating sows (6) and in rodents (7-9), but it is not clear whether this was due to an effect at the level of the hypothalamus or anterior pituitary.

We investigated the site of action of opioid peptides in modulating $G H$ during lactation in the pig. To accomplish this we utilized lactating sows that had been actively immunized against GRF [GRF(1-29)-(Gly) $\left.{ }_{4}-\mathrm{Cys}-\mathrm{NH}_{2}\right]$ conjugated to human serum albumin (GRF-HSA) or HSA alone (10). This allowed differentiation of the effects of suckling on GH at the level of the hypothalamus, hypophysis or both. 


\section{MATERIALS AND METHODS}

Crossbred gilts that had been previously immunized against GRF-HSA $(n=5)$ or HSA $(n=4)$ were used $(10)$. Immunizations were initiated at $180 \pm 1$ day of age and boosters were given at $243 \pm 1$ and $271 \pm 1$ day of age (10). Antibody titers, expressed as dilution of serum required to bind $50 \%$ of 125 IGRF, averaged $32,000 \pm 8916$ and $36,800 \pm 5,248$ at 243 and 271 day of age, respectively. Primary and booster immunizations were accomplished by injecting pigs with 2 and $1 \mathrm{mg}$, respectively, of a GRF(1-29)- $\mathrm{NH}_{2}$ analog, GRF(1-29)-(Gly) - $^{-C y s}-\mathrm{NH}_{2}$, designed to be specifically conjugated at the carboxyl terminus of an equal amount of HSA (GRF-HSA) or HSA alone. Conjugation of the GRF analog and HSA was performed by the m-maleimido-benzoyl- $\mathrm{N}$ hydroxy-succinimide procedure (11).

Gilts were mated to crossbred boars at first estrus detected beyond $271 \pm$ 1 day of age. A booster immunization of $1 \mathrm{mg}$ of GRF-HSA or HSA was given at day $97 \pm 2$ of gestation. Blood samples were obtained via venipuncture on day 109 of gestation for determination of antibody titers against GRF.

Litter sizes were standardized within treatment during $48 \mathrm{hr}$ after parturition. Sows and pigs were penned in individual farrowing crates throughout lactation and sows were fed to appetite twice daily according to NRC recommendations (12). Litter size on day 21 of lactation was $8.3 \pm 0.3$ and $7.2 \pm 0.6$ pigs for HSA and GRF-HSA sows, respectively.

Catheters were inserted into the vena cava via a jugular vein on day 19 of lactation. Naloxone and saline were administered on day 21 of lactation. Sows received (i.v.) naloxone $(0.25 \mathrm{mg} / \mathrm{kg} /$ injection) or saline $(0.0125 \mathrm{ml} / \mathrm{kg} /$ injection) every $15 \mathrm{~min}$ from 0800 to 1045 or 1400 to 1645 according to a crossover design. Sows in replicate 1 received saline during the AM and naloxone during the PM (GRF-HSA, $n=3 ; H S A, n=2$ ), whereas sows in replicate 2 received naloxone during the AM and saline during the PM (GRF-HSA, $n=2 ; H S A, n=2$ ). Sows were fed $1.35 \mathrm{~kg}$ of a corn-soybean meal diet at 0700 and at 1300 . Blood samples were collected at 15 -min intervals from 0730 to 1200 and from 1330 to 1800 . Naloxone or saline was administered immediately after obtaining a blood sample. Samples were stored at $4 \mathrm{C}$ for $18 \mathrm{hr}$, centrifuged at $3,000 \mathrm{x}$ $\mathrm{g}$ for $30 \mathrm{~min}$ and serum was decanted and stored at $-20 \mathrm{C}$ until assayed. All samples were analyzed for GH and LH and samples collected at 0730,0800 , $0930,1030,1130,1330,1400,1530,1630$ and 1730 were analyzed for PRL.

Antibody titers against GRF were determined as previously described (10) by incubating various dilutions of serum with ${ }^{125}$ I-GRF (1-29)-NH $\mathrm{NH}_{2}$. Dilutions of serum were made in $0.02 \mathrm{M}$ sodium phosphate ( $\mathrm{PH}=7.2$; GRF buffer). Antibody titer was expressed as initial dilution required to bind $50 \%$ of ${ }^{125}$ IGRF in GRF-HSA sows or percentage binding at a dilution of 1:100 in HSA sows. Non-specific binding was consistently less than $1 \%$.

On day 1 , diluted serum $(0.4 \mathrm{ml}$ assayed in duplicate), GRF buffer $(0.1 \mathrm{ml})$ and ${ }^{125 I}$-GRF $(0.1 \mathrm{ml}, 10.12,000 \mathrm{cpm}$ in GRF buffer) were aliquoted into plain glass tubes, mixed with a vortex and incubated for 18 to $24 \mathrm{hr}$ at $4 \mathrm{C}$. Nonspecific binding was determined by incubating $0.5 \mathrm{ml}$ GRF buffer with ${ }^{125}$ IGRF. On day 2, goat anti-pig gamma globulin $(0.1 \mathrm{ml}, 1: 2$ in GRF buffer) and normal pig serum $(0.1 \mathrm{ml}, 4 \%$ in GRF buffer) was added to all tubes, mixed with a vortex and incubated at $4 \mathrm{C}$ for $10 \mathrm{~min}$. Bound and free ${ }^{125} \mathrm{I}-\mathrm{GRF}$ were separated by adding $1 \mathrm{ml}, 6 \%$ poly-ethyleneglycol in GRF buffer, incubating for $1 \mathrm{hr}$ and centrifuging at $3000 \times \mathrm{g}$ for $40 \mathrm{~min}$. 
Radio-labeled GRF was prepared by incubating GRF (10 $\mu \mathrm{g}$ in $20 \mu 10.6 \mathrm{~N}$ ammonium acetate), $1 \mathrm{mCi}{ }^{125} \mathrm{I}$ and $2 \mu \mathrm{g}$ iodogen (1, 3, 4, 6 - tetrachloro-3 alpha, 6 alpha-diphenylglycouril) for $8.5 \mathrm{~min}$. The reaction was stopped by transferring the mixture to a $30 \times 0.7 \mathrm{~cm}$ carboxymethyl cellulose column preconditioned with ammonium acetate buffer $(0.002 \mathrm{~N} ; \mathrm{pH}=7.2)$. Labeled GRF was eluted with increasing concentrations of ammonium acetate 0.01 to $0.6 \mathrm{~N})$.

Concentrations of GH were measured by procedures previously validated (10) using antiserum provided by A. F. Parlow (AFP 10318545). Average intraand inter-assay CV's were $5.4 \%$ and $9.7 \%$, respectively. Luteinizing hormone was measured as previously validated (13) with modifications (14). Intra-assay $\mathrm{CV}$ was $16.4 \%$. Concentrations of PRL were quantified according to validated procedures (15). Intra-assay $\mathrm{CV}$ was $13.8 \%$.

Data for serum concentrations of LH, GH and PRL were analyzed by splitplot analyses of variance (16) using general linear models (17). The full model utilized for GH, LH and PRL included treatment (GRF vs GRF-HSA), replicate ( 1 vs 2), treatment $\times$ replicate, sow within treatment $\times$ replicate, period (naloxone vs saline), period $x$ treatment, time and two-way interactions involving time. Effect of treatment, replicate and treatment $x$ replicate were tested using the sow within treatment $x$ replicate mean square as the error term; period and period $x$ treatment were tested using the period $x$ sow within treatment mean square as error term. Initial analyses indicated that replicate or the treatment $x$ replicate interaction did not contribute $(P>0.5)$ to variation in GH; therefore, subsequent analyses did not include replicate or treatment $x$ replicate. Split-plot analyses were then performed within treatment and within treatment and period to more clearly define the effects of naloxone and time, respectively, on GH. In order to more clearly ascertain temporal changes in $\mathrm{GH}$, data were broken down into hourly periods before $(-30,-15$ and $0 \mathrm{~min}$ before injection; $0 \mathrm{hr}$ ) and after initial injection of naloxone or saline $(1,2$, 3 and $4 \mathrm{hr}$ ). Models as previously described were utilized with the exception that time was replaced by hour. Hourly means were separated using StudentNewman Keuls test. The treatment and period $x$ treatment effects did not contribute to variation in $L H$ and PRL, thus data were pooled across treatment.

An episode of GH or LH release was defined as values that exceeded a previous nadir by at least $50 \%$ and the increase had to be greater than the sensitivity of the assay. Basal GH was defined as the mean of all samples during a sampling period excluding those associated with episodic release of GH. Frequency of release and basal GH were analyzed by one way analyses of variance using a model that included treatment (GRF vs GRF-HSA), period (naloxone vs saline) and period $x$ treatment.

\section{RESULTS}

Antibody titers against GRF on day 109 of gestation and day 21 of lactation were $12,000 \pm 2,832$ and $9,100 \pm 1,629$, respectively. Titers ranged from 2,000 to 16,000 in GRF-HSA gilts on day 21 . Serum for HSA pigs bound $<10 \%$ at $1: 100$.

Characteristics of GH secretion in lactating sows immunized against GRFHSA or HSA and administered naloxone or vehicle (saline) are in Table 1. Average GH from -30 to $240 \mathrm{~min}$ from initiation of saline is in Figure 1 . Active immunization against $G R F$ decreased $(P<0.05)$ average concentrations of $G H$ 
Table 1. Effect of Naloxone on Average ( \pm Sem) Characterustics of Secretion of GH in Sows IMMUNIZED AGAINST HSA OR GRF-HSA.

\begin{tabular}{|c|c|c|c|c|c|c|}
\hline & \multicolumn{2}{|c|}{ Average $\mathrm{GH}, \mathrm{ng} / \mathrm{ml}$} & \multicolumn{2}{|c|}{ Basal $\mathrm{GH}, \mathrm{ng} / \mathrm{ml}$} & \multicolumn{2}{|c|}{ Frequency, peaks $/ 4 \mathrm{hr}$} \\
\hline & Saline & Naloxone & Saline & Nalaoxone & Saline & Naloxone \\
\hline $\begin{array}{l}\text { HSA } \\
\text { GRF-HSA }\end{array}$ & $\begin{array}{l}4.8 \pm 0.2^{\mathrm{abb}} \\
2.6 \pm 0.1^{\mathrm{b}}\end{array}$ & $\begin{array}{l}3.2 \pm 0.1^{2} \\
2.0 \pm 0.1\end{array}$ & $\begin{array}{c}4.1 \pm 0.2^{\mathrm{a}} \\
2.4 \pm 0.1^{\mathrm{b}}\end{array}$ & $\begin{array}{l}3.2 \pm 0.1^{2} \\
2.0 \pm 0.1\end{array}$ & $\begin{array}{c}1.5 \pm 0.3^{2, b} \\
0.4 \pm 0.2\end{array}$ & $\begin{array}{l}0 \pm 0 \\
0 \pm 0\end{array}$ \\
\hline
\end{tabular}

aP $<0.05$, HSA vs GRF-HSA.

'P $<0.05$, saline vs naloxone.

(Table 1, Figure 1), by suppressing episodic release of GH (Table 1). Immunization against GRF-HSA also decreased basal GH concentrations (Table 1).

Changes in average GH from 0 to $4 \mathrm{hr}$ from naloxone or saline in GRF-HSA and HSA immunized sows are shown in Figure 2. Initial analysis revealed that treatment, period, hour and the period $x$ hour interaction contributed ( $P<$ 0.01 ) to variation in GH. The treatment $x$ period and treatment $x$ hour interactions were not significant $(P>0.10)$. In GRF-HSA and HSA immunized sows, concentrations of GH were lower $(P<0.05)$ at $1,2,3$ and 4 hr than at $0 \mathrm{hr}$ from initial injection of naloxone; however, concentrations of $\mathrm{GH}$ at hours $0,1,2,3$ and 4 from saline were similar in all sows (Figure 2). Episodes of $\mathrm{GH}$ release were not detected in any sow from 15 to $240 \mathrm{~min}$ after initiation of naloxone. Frequency of release of GH (Table 1) was suppressed by naloxone, but not saline, in HSA sows. Basal $G H$ was not decreased $(P>0.10)$ by naloxone in HSA sows (Table 1 ). Frequency of $\mathrm{GH}$ release was not decreased $(P>0.10)$ by naloxone in GRF-HSA immunized sows; however, basal GH was decreased (P $<0.05$ ) by naloxone, but not saline, in GRF-HSA immunized sows (Table 1).

Concentrations of PRL were not altered by immuno-neutralization of GRF (data not presented). Serum concentrations of PRL from -30 to $210 \mathrm{~min}$ from saline or naloxone averaged across GRF-HSA and HSA immunized gilts are depicted in Figure 3. Naloxone resulted in a decrease in PRL at 90, 150 and $210 \mathrm{~min}$ after initiation of injections.

Serum LH was not altered by immunization against GRF (data not shown) nor by administration of naloxone (Figure 4). Concentrations of LH in all sows were near the assay sensitivity $(.2 \mathrm{ng} / \mathrm{ml})$ and overall frequency of $\mathrm{LH}$ release averaged $0.25 \pm 0.25$ peaks $/ 4 \mathrm{hr}$.

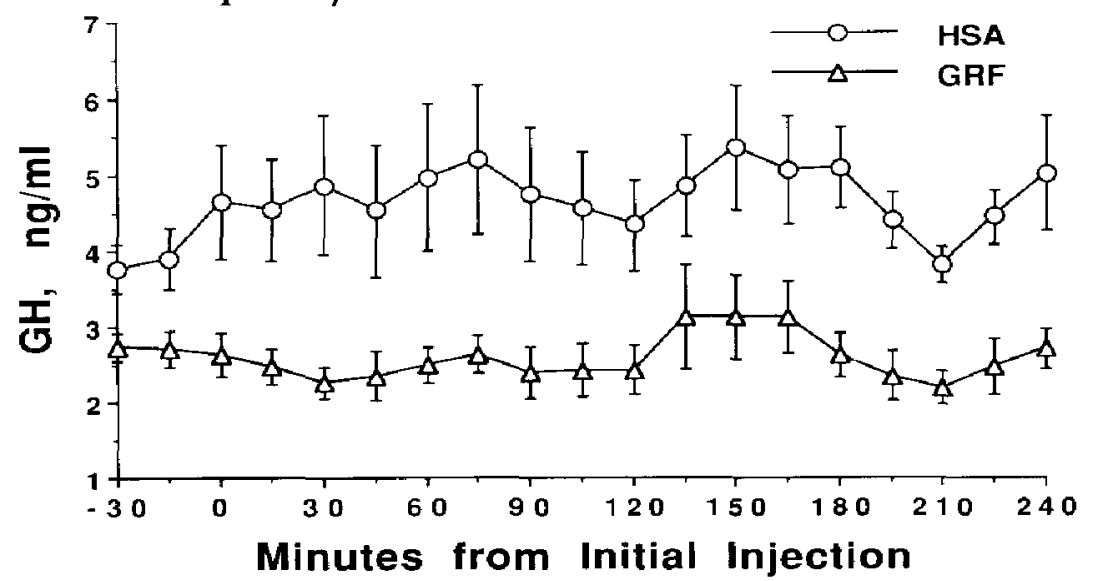

Fig. 1. Changes in average GH in sows immunized against GRF-HSA or HSA alone. Saline was administered at $15-\mathrm{min}$ intervals from 0 to $165 \mathrm{~min}$. Concentrations of $\mathrm{GH}$ were lower $(P<0.05)$ in GRF-HSA than in HSA sows. Values are the mean \pm SEM of four (HSA) or five (GRF-HSA) sows. 


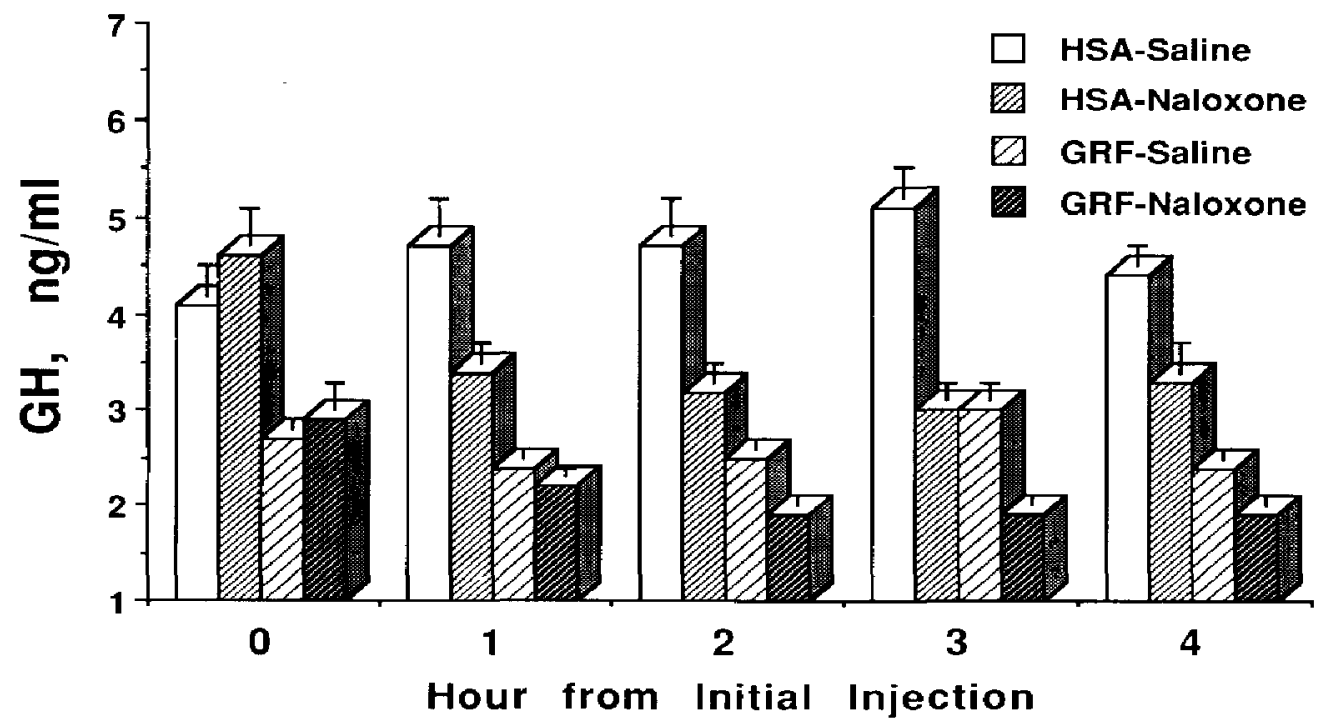

Fig. 2. Effect of saline or naloxone on GH in sows immunized against HSA or GRF-HSA administered saline or naloxone. Naloxone or saline was administered during hour 1,2 and 3 . Concentrations of $\mathrm{GH}$ were lower $(\mathrm{P}<0.05)$ following naloxone than saline in both sows immunized against HSA and sows immunized against GRF. Values represent the mean + SEM of 3 ( 0 hr) or 4 (1,2, 3, 4 hr) samples per sow (HSA, $n=4$; GRF-HSA, $n=5$ ).

\section{DISCUSSION}

These data demonstrate that elevated concentrations of GH in the lactating pig are primarily due to an opioid modulated increase in GRF. Active immunization against GRF abolished episodic secretion of GH, thereby lowering average blood concentration. Wehrenberg (18) demonstrated that passive immunization against GRF lowered basal and suckling-stimulated concentrations of GH in the rat. Antagonism of opioid receptors in control (HSA) sows resulted in a decrease in concentration and frequency of GH release, similar to values in saline-treated GRF-immunized sows (Figure 2). Other reports have demonstrated that naloxone decreased GH in suckled rat (7-9) and pig (6). An

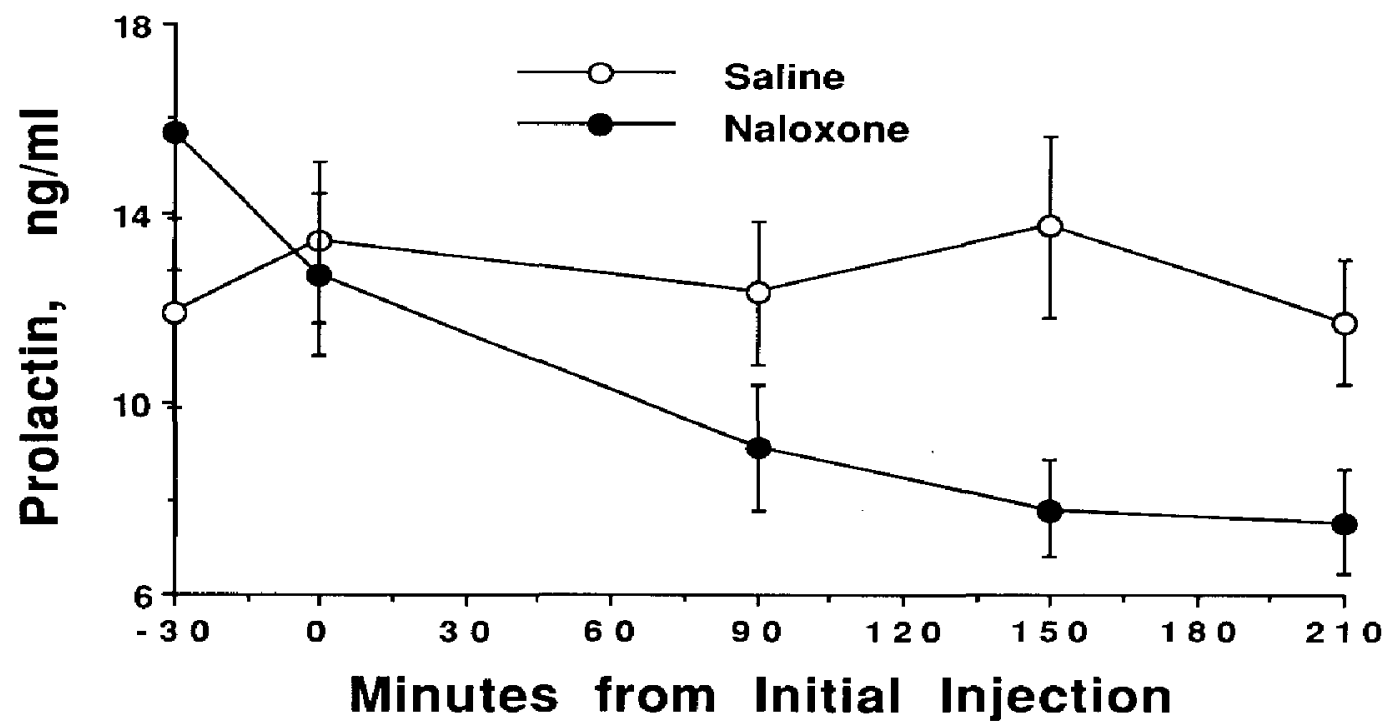

Fig. 3. Average PRL from -30 to $210 \mathrm{~min}$ from saline or naloxone. Concentrations of PRL were similar $(P>0.10)$ in GRF-HSA and HSA sows, thus data were pooled. Naloxone or saline was administered at 15 -min intervals from $O$ to $165 \mathrm{~min}$. Serum PRL decreased following naloxone (P $<0.05$ ) but not following saline. Values are the mean \pm SEM of four (HSA) or five (GRF-HSA) sows. 


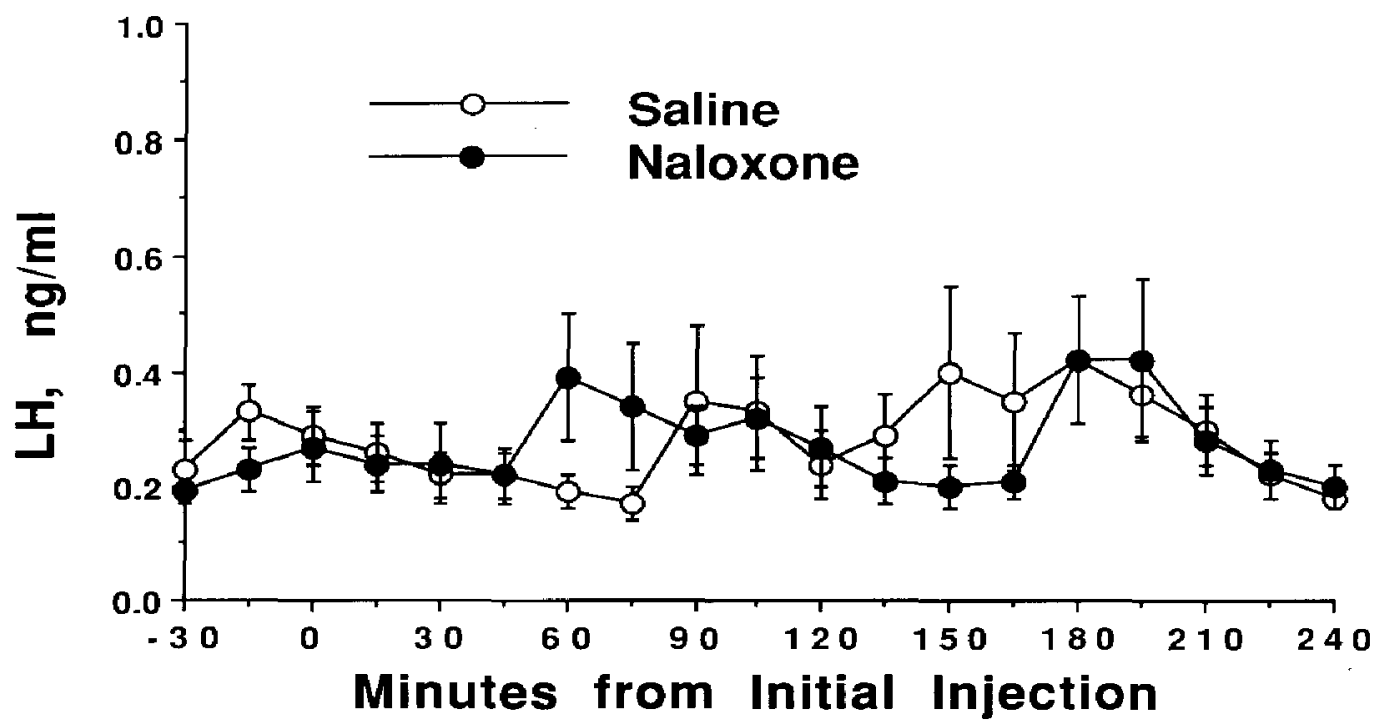

Fig. 4. Average LH from -30 to $210 \mathrm{~min}$ from saline or naloxone. Concentrations of LH were similar $(P>0.10)$ in GRF.HSA and HSA sows, thus data were pooled. Naloxone or saline was administered at $15-\mathrm{min}$ intervals from 0 to $165 \mathrm{~min}$. Concentrations of LH were similar (P $>$ $0.10)$ following saline or naloxone. Values represent the mean \pm SEM of four (HSA) or five (GRF. HSA) sows.

effect of opioids on GH during lactation is also supported by the observation that an opioid agonist increases GH in lactating beef cows (19).

Although the primary role of opioids in mediating the effects of suckling on GH are apparently via GRF, these results demonstrate an effect on GH independent of GRF. Antagonism of opioid receptors with naloxone in sows immunized against GRF resulted in a small, but significant decrease in GH (Figure 2). In addition, naloxone decreased basal $\mathrm{GH}$ in gilts immunized against GRFHSA, but not HSA. This effect may be unique to lactation and (or) during suckling, because active immunization against GRF in cyclic gilts did not lower basal GH, while episodic release of $\mathrm{GH}$ was abolished (10). The exact nature of this non-GRF dependent effect of opioids on GH cannot be determined from these data. However, hypophyseal stalk transection of the pig elevates basal GH, due to decreased amount of somatostatin reaching the pituitary (20). Thus, suckling may alter GH by decreasing somatostatin and increasing GRF.

These results corroborate our earlier report that opioids stimulate $G H$ in swine (10) and ruminants $(21,22)$ primarily through a hypothalamic mechanism. Passive immunization of rats against GRF blocked the stimulatory effect of morphine (23), beta-endorphin (24) or FK33-824 $(8,25-27)$ on release of GH. Met-enkephalin fibers are located in close proximity to GRF cell bodies in the median eminence of the rat (28) and release of $\mathrm{GH}$ from porcine somatotropes in vitro was not affected by enkephalin analogs (29).

Results from this experiment extend previous results $(2,5)$ that suckling affects PRL in sows through a mechanism that involves opioids. Others reported that agonists of opioids elevated PRL (30, 31). Suckling caused an increase in PRL and beta-endorphin in rats (32) and sheep (33).

Failure of naloxone to increase episodic release of $\mathrm{LH}$ in primiparous lactating sows conflicts with previous results that infusion of naloxone, at concentrations similar to those used in this study, increased frequency of LH release (2), or a single injection of naloxone increased $\mathrm{LH}(4,5)$ in lactating multiparous sows. This discrepancy is likely to be related to the fact that primiparous sows 
were used in this study, whereas multiparous sows were used in previous studies $(2,4,5)$. Intervals from weaning to estrus are typically longer and concentrations of LH lower in primiparous than in multiparous sows (1). Further studies are necessary to evaluate the role of opioids in mediating the effects of suckling on LH in primiparous sows.

In summary, antagonism of opioid receptors with naloxone decreased GH in lactating primiparous sows immunized against GRF-HSA or HSA. A decrease in GH in sows with GRF immuno-neutralized indicates that a portion of the effects of suckling on GH are not dependent on GRF.

\title{
ACKNOWLEDGMENTS AND FOOTNOTES
}

\begin{abstract}
1 Paper No. 12202 of the Journal Series of the North Carolina Agric. Res. Serv., Raleigh 27695 7643. Use of trade names in this publication does not imply endorsement by the North Carolina Agric. Res. Serv. nor criticism of similar products not mentioned.

We thank T. Steffel and S. Wagoner for care of animals; M. Galloway, V. Hedgpeth, B. Flowers, D. Herman, P. Stricker, L. Tiller and C. Marsh for technical assistance; Dr. L.E. Reichert for pig LH and prolactin; Dr. G.D. Niswender for antiserum to pig LH; Dr. A.F. Parlow through the National Hormone and Pituitary Program, NIADDK and Dr. D. Bolt for porcine GH and antiserum to pig GH; and E.I DuPont de Nemours \& Co. for naloxone.
\end{abstract}

\section{REFERENCES}

1. Britt JH, Armstrong JD, Cox NM, Esbenshade KL. Control of follicular development during and after lactation in sows. J Reprod Fertil Suppl 33:37, 1985.

2. Armstrong JD, Kraeling RR, Britt JH. Effects of naloxone or transient weaning on secretion of LH and prolactin in lactating sows. J Reprod Fertil 83:301,1988.

3. Armstrong JD, Kraeling RR, Britt JH. Morphine suppresses luteinizing hormone concentrations in transiently weaned sows and delays onset of estrus after weaning. J Anim Sci $66: 2216,1988$.

4. Barb CR, Kraeling RR, Rampacek GB, Whisnant CS. Opioid inhibition of luteinizing hormone secretion in the postpartum lactating sow. Biol Reprod 35:368, 1986.

5. Mattioli M, Conte F, Seren E, Galeati G. Effect of naloxone on plasma concentrations of prolactin and LH in lactating sows. J Reprod Fertil 76:167, 1986.

6. Schneller HE, Cox NM, Rainey MR. Effect of naloxone administration to estrogentreated lactating sows on luteinizing hormone, growth hormone and ovulation. J Anim Sci 67 (Suppl 1):409, 1987.

7. Sirinathsinghji DJS, Martini L. Effects of bromocryptine and naloxone on plasma levels of prolactin, LH and FSH during suckling in the female rat: Responses to gonadotrophin releasing hormone. J Endocrinol 100:175, 1984.

8. Ferland L, Kledzik GS, Cusan L, Labrie F. Evidence for a role of endorphins in stress- and suckling-induced prolactin release in the rat. Mol Cel Endocrinol 12:267, 1978.

9. Miki N, Sonntag WE, Forman LJ, Meites J. Suppression by naloxone of rise in plasma growth hormone and prolactin induced by suckling. Proc Soc Exp Biol Med 168:330, 1981.

10. Armstrong JD, Esbenshade $\mathrm{KL}$, Johnson JL, Coffey MT, Heimer E, Campbell RM, Mowles T, Felix A. Active immunization of pigs against growth hormone releasing factor: Effect on concentrations of growth hormone and insulin-like growth factor 1. J Anim Sci 68:427, 1990.

11. Green N, Alexander H, Olson A, Alexander S, Shinnick TM, Sutcliffe JG, Lerner RA. Immunogenic structure of the influenza virus hemagglutinin. Cell 28:477, 1982.

12. NRC. Nutrient requirements of pigs. 9 th ed, National Academy of Science, Washington, $\mathrm{DC}, 1988$.

13. Stevenson JS, Cox NM, Britt JH. Role of the ovary in controlling luteinizing hormone, follicle stimulating hormone, and prolactin secretion during and after lactation in pigs. Biol Reprod 24:341, 1981.

14. Armstrong JD, Britt JH. Nutritionally-induced anestrus in gilts: metabolic and endocrine changes associated with cessation and resumption of estrous cycles. $J$ Anim Sci $65: 508,1987$. 
15. Kraeling RR, Rampacek GB, Cox NM, Kiser TE. Prolactin and luteinizing hormone secretion after bromocryptine (CB-154) treatment in lactating sows and ovariectomized gilts. J Anim Sci 54:1212, 1982.

16. Gill JL, Hafs HD. Analysis of repeated measurements of animals. J Anim Sci 33:331, 1971.

17. SAS. SAS/STAT Guide for Personal Computers, Version 6 Edition. SAS Institute Inc., Cary, NC, 1985.

18. Wehrenberg WB, Gaillard RC. Neuroendocrine mechanisms regulating growth hormone and prolactin secretion during lactation. Endocrinol 124:464, 1989.

19. Lloyd KE, Armstrong JD, Esbenshade KL, Heimer E, Campbell R, Mowles T, Felix A. Active immunization of cows against growth hormone releasing factor. $J$ Anim Sci 66(Suppl 1):406, 1988.

20. Klindt J, Ford JJ, Berardinelli JG, Anderson LL. Growth hormone secretion after hypophysial stalk transection in pigs. Proc Soc Exp Biol Med 172:508, 1983.

21. Armstrong JD, Johnson BH. Agonists of endogenous opioid peptides suppress LH, and stimulate cortisol and growth hormone during the follicular phase in heifers. J Endocrinol 121:11, 1989.

22. Armstrong JD, Spears JW. An endogenous opioid peptide agonist elevates concentrations of growth hormone in ruminants. J Anim Sci 66(Suppl 1):391, 1988.

23. Wehrenberg WB, Brazeau $P$, Luben $R$, Ling $N$, Guillemin $R$. A noninvasive functional lesion of the hypothalamo-pituitary axis for the study of growth hormone-releasing factor. Neuroendocrinol 36:489, 1983.

24. Wehrenberg WB, Bloch B, Ling N. Pituitary secretion of growth hormone in response to opioid peptides and opiates is mediated through growth hormone-releasing factor. Neuroendocrinol $41: 13,1985$.

25. Katakami $H$, Kato $Y$, Matsushita $N$, Shimatsu A, Imura $H$. Possible involvement of (gamma)-aminobutyric acid in growth hormone release induced by a mets-enkephalin analog in conscious rats. Endocrinol 109:1033, 1981.

26. Murakami $Y$, Kato $Y$, Kabayama $Y$, Inoue $T$, Tojo $K$, Ohta $H$, Imura $H$. Inhibition by antiserum to rat growth hormone-releasing factor of growth hormone secretion induced by a met-enkephalin analog, FK33-824, in rats. Proc Soc Exp Biol Med 178:151, 1985 .

27. Murakami $Y$, Kato $Y$, Kabayama $Y$, Tojo $K$, Imorre $T$, Imura $H$. Involvement of growth hormone (GH)-releasing factor in GH secretion induced by serotoninergic mechanisms in conscious rats. Endocrinol 119:1089, 1986.

28. Daikoku S, Hisano S, Kawano H, Chikamori-Aoyama M, Kagotani Y, Zhang R, Chihara $K$. Ultrastructual evidence for neuronal regulation of growth hormone secretion. Neuroendocrinol 47:405, 1988.

29. Glenn KC. Regulation of release of somatotropin from in vitro cultures of bovine and porcine pituitary cells. Endocrinol 118:2450, 1986.

30. Meites J, Bruni JF, Van Vugt DA, Smith AF, Fioretti P. Relation of endogenous opioid peptides and morphine to neuroendocrine functions. Life Sci 24:1325, 1979.

31. Shaar CJ, Clemens JA. The effects of opiate agonists on growth hormone and prolactin release in rats. Federation Proc 39:2539, 1980.

32. Riskind PN, Millard WJ, Martin JB. Opiate modulation of the anterior pituitary hormone response during suckling in the rat. Endocrinol 114:1232, 1984.

33. Gordon K, Renfree MB, Short RV, Clark IJ. Hypothalamo-pituitary portal blood concentrations of beta-endorphin during suckling in the ewe. J Reprod Fertil 79:397, 1987. 